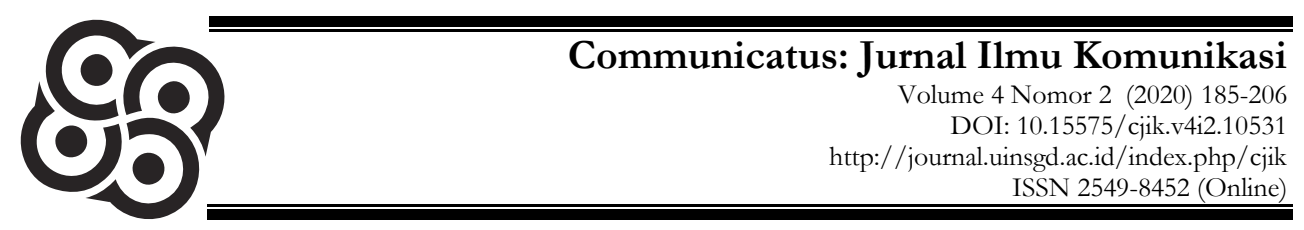

\title{
Wartawan dan Netralitas Media
}

\author{
Darajat Wibawa ${ }^{1 *}$ \\ ${ }^{1}$ UIN Sunan Gunung Djati Bandung \\ * email.darajatwibawa@uinsgd.ac.id
}

\begin{abstract}
This study is Journalists and Media Reality (Qualitative Research in Bandung City) aims to determine the definition of journalists in Bandung City towards media reality, the trigger factors for media neutrality adoption, and how the effect of implementing media neutrality on journalists. In order to provide an overview and experience of media neutrality experienced by journalists in the city of Bandung, this study is more suitable to use a descriptive qualitative approach. Based on unstructured interviews and role observations with five journalists, the results showed that the informants gave a very diverse and complex definition of media neutrality, but in principle it led to the word impartial. The informants also admitted that implementing neutrality was due to the awareness to carry out their obligations as journalists. Meanwhile, the effect of implementing media neutrality is focused on two poles, namely positive so that they become professional journalists and negative so that they become unprofessional journalists. This research has an impact on the actualization of journalists' activities while carrying out their profession, so that journalists are still obliged to uphold neutrality.
\end{abstract}

Keyword: Neutrality, Journalists, Media

\begin{abstract}
ABSTRAK
Penelitian ini betujuan untuk mengetahui pengertian wartawan di Kota Bandung terhadap netralitas media, faktor pemicu pengiplementasian netralitas media, dan bagaimana efek pengiimplementasian netralitas media terhadap wartawan. Guna memberikan gambaran dan pengalaman mengenai netralitas media yang dialami oleh para wartawan di Kota Bandung, penelitian ini menggunakan metode deskriptif dengan pendekatan kualitatif. Pengmpulan data dilakukan dengan wawancara tidak terstruktur dan pengamatan berperan kepada lima wartawan, hasil penelitian menunjukkan bahwa, para informan memberikan pengertian netralitas media yang sangat beragam dan kompleks namun pada prinsipnya mengarah pada kata tidak berpihak. Para informan juga mengakui mengimplementasikan netralitas adalah karena kesadaran untuk melaksanakan kewajiban sebagai wartawan. Sedangkan efek pengimplementasian netralitas media tertuju pada dua kutub, yaitu positif sehingga menjadi wartawan profesional dan negatif sehingga menjadi wartawan yang tidak profesional. Penelitian ini berdampak pada aktualisasi aktivitas wartawaan saat menjalankan profesinya, sehingga wartawan tetap berkewajiban menjungjung tinggi netralitas.
\end{abstract}

\section{Kata Kunci: Netralitas, Wartawan, Media}




\section{PENDAHULUAN}

Sampai dengan saat ini, Indonesia adalah negara yang memiliki perkembangan media massanya berkembang begitu pesat. Sendjaja, mengatakan, perkembangan mass media di Indonesia memiliki tiga ciri: (1) Manajemen bisnis di bidang media massa kini tidak lagi berbentuk yayasan dan hanya mengedepankan aspek ideal, melainkan berbasis pada perseroan yang terbatas (PT) yang didukung oleh sistem manajemen yang lebih profesional dan menggunakan karya teknis yang kompleks dan mengarah ke komersialisasi. (2) Semakin banyak pengusaha atau perusahaan nasional yang biasa disebut kelompok yang memfokuskan modalnya untuk berbisnis di mass media. (3) Mass media yang ada semakin beragam dan tentu saja mengarah pada aspek spesialisasi (Sendjaja, 2006)

Perubahan ini membawa Indonesia menjadi negara yang sesak dengan media massa. Media massa Indonesia telah mengalami transformasi dari apa yang disebut media perjuangan yang penuh nilai idealis menjadi media komersial yang mengedepankan nilai komersial, sehingga terkadang media massa Indonesia meninggalkan proses jurnalistik yang beretika.

Dalam bukunya Mass Communication Theories, McQuail menyebutkan, setiadanya untuk melihat peran media setiadanya terdapat enam tinjauan atau perspektif. Keenan perspektif tersebut adalah 1). Media massa dilihat sebagai window on event and experience. 2). Media dianggap sebagai a mirror of event in society and the world, implying a faithful reflection. 3). Media dianggap sebagai filter, atau gatekeeper yang bertugas menyeleksi apapun agar memperoleh perhatian atau malah tidak. 4). Media dipandang sebagai guide, interpreter atau petunjuk. 5). Media dilihat sebagai forum guna mempresentasikan informasi dan berbagai ide untuk khalayak. 6). Media sebagai interlocutor (McQuail, 2015).

Media massa dengan pasti bisa memengaruhi pemikiran serta tindakan khalayak mengenai dampak komunikasi massa pada persepasi, pengetahuan, perilaku dan sikap masyarakat. Media juga agen sosialisasi atau penyebar nilainilai yang memainkan berbagai peranan penting dalam transmisi sikap), pikiran dan hubungan interaksional (Mulyana, 2001). Prinsipnya, media massa adalah organisasi kemasyarakatan yang bertugas mencari, menyimpan, mengolah dan mempublikasikan karya jurnalistik berupa suara dan gambar, bentuk tulisan, juga grafik dan data dengan memanfaatka media elektrnik dan cetak. Salah satu ruh yang perlu dijaga dalam media massa adalah netralitas. Namun kenyataannya tidak demikian, bahnyak pihak memandang kehidupan media massa di Indonesia saat ini sudah meninggalkan netralitas.

Pandangan tersebut bisa jadi tidak semuanya benar atau tidak semuanya salah, sebab diakui atau tidak belakangan ini banyak prodak yang dianggap tidak memiliki nilai netralitas oleh masyarakat padahal pengelola media massa 
sudah memploklamirkan diri bawa prodak jurnalistik yang akan disampaikan kepada masyarakat adalah netral. Pro dan kontra keberpihakan media merupakan satu di antara ribuan kasus yang menimpa media massa Indonesia. Selain itu, tudingan keberpihakan yang sering ditunjukkan media massa Indonesia mulai meresahkan masyarakat. Oleh karena itu, ketidakpuasan masyarakat terhadap netralitas media Indonesia sudah tidak bisa ditutup-tutupi lagi, sudah terang benderang dan terlihat secara kasat mata oleh masyarakat.

Pertanyaan yang sering timbul di masyarakat adalah: 1). Benarkah berita yang dihasilkan media memiliki nilai berita tanpa opini wartawan? 2). Apakah berita yang diproduksi media memang cermin realitas sesungguhnya? 3). Bagaimana idealisme media? 4). Bagaimana perkembangan media massa partisan yang sengaja dibuat pihak tertentu untuk kepentingan tertentu pula? 5). Benarkah berita yang diproduksi media merupakan realitas objektif?

Dalam kegiatan jurnalistik yang memerlukan fasilitas media massa, prinsip independensi dan netral. Sikap netral sangat perlu untuk ditegakkan, sebab ruh aktivitas media massa adalah merdeka ketika hendak mengimplementasikan ideologi jurnalisme di lapangan, serta bersikap netral yang memunculkan keberimbangan, memiliki tingkat akurasi yang tinggi dan tentu saja tidak memiliki keberpihakan kemanapun kecuali berpihak pada kepentingan pihak orang banyak atau massa. Oleh karena itu, media massa memiliki sikap untuk selalu menjungjung tinggi netralitas, dan jangan berpikir bisa terpengaruh kepentingan politik maupun kepentingan ekonomi semata.

Sikap tersebut perlu dipertegaskan kembali sebab banyak segelintir orang yang berkuasa secara politis menguasai bahkan menjadi pemilik media. Selain itu, media massa harus menjaga proporsi pemberitaan yang tepat dan menyadari perannya sebagai pemberi informasi, menyampaikan pesan pendidikan, melakuan kontroling, dan sebagai perekat sosial untuk membangun terciptanya budaya kehidupan demokrasi yang tetap berkualitas. Rasanya tidak akan menghasilkan apa-apa jika penegakan netralitas hanya diupayakan dan dilakukan oleh lembaga media massa tanpa mengikutsertakan sosok wartawan untuk sama-sama menegakkan netralitas. Diakui atau tidak, wartawan maupun media massa yang mampu menegakkan netralitas dengan sendirinya akan mudah mejadi media yang kapabel dan wartawan yang profesional.

Sebenarnya penelitian berkaitan dengan netralitas media massa sudah dilakukan sebelumnya oleh beberapa peneliti lainnya di antaranya oleh Ajeng Dwi Wardani \& Heni Indrayani, Emmy Poentari, Musfialdy, dan Komaruddin Hasan. Penelitian yang dilakukan Ajeng Dwi Wardani \& Heni Indrayani berjudul Netralitas Konten Berita Online: Analisis Praming: Berita Reuni Alumni 212 di Detic.com) Hasil penelitian Ajeng menyimpulkan detik.com telah menerapkan prinsip netralitas media. Selain itu, detik.com tampaknya lebih berfokus pada pemakaian komponen berita "apa " dan elemen "untuk 
siapa" untuk mendeskripsikan suatu isu yang bersifat lebih objektif (Wardani \& Indrayani, 2018).

Emmy Poentari peneliti lainnya meneliti tentang Komperasi, Kebenaran, Relevansi, Keseimbangan, dan Netralitas dalam Pemberitaan (Studi Konten Analisis Terkait Pemberitaan Pemilu Presiden 2014 di Harian Kompas dan Koran Sindo. Penelitian ini merangkum empat kategori. Yaitu kategori kebenaran, reevansi, berimbang, dan netralitas. Pada aspek kebenaran, Kompas memiliki tingkat faktualitas yang tinggi jika dikomparasi dengan surat kabar Sindo. Pada aspek relevansi, surat kabar Kompas penyajian berita kampanye saat pemilu Presiden 2014 cenderung lebih menjaga unsur faktualitas sedangkan Koran Sindo masih ditemukan berita yang sensasionalisme dan dramatisasi.

Pada aspek keberibangan, surat kabar Kompas dan surat kabar Sindo mempunyai kinerja yang cenderung sama yakni sama-sama menyajikan nara sumber yang tidak berimbang dengan demikian lebih menonjolkan teknik liputan satu sisi (one side cover) saja dari pada berbagai sisi (cover both side). Pada aspek netralitas, surat kabar Kompas cenderung bersifat objektif, proporsional dan memberi porsi kemunculan yang berimbang, sedangkan Koran Sindo nampaknya cenderung objektif (Poentarie, 2015). Penelitian berikutnya dilakukan oleh Musfialdy dengan judul Independen Media: Pro-Kontra Objetivitas dan Netralitas Pemberitaan Media. Dalam papaer nya Musfialdy menyimpulkan, sebuah berita sebagai isi media adalah hasil konstruksi realistis. Media massa memiliki peluang besar untuk mempengaruhi makna dan citra realitas yang dikonstruksinya. Berita adalah konstruksi realitas, ditambah ideologi dan kepentingan media itu sendiri (Musfialdy, 2019).

Kamaruddin Hasan juga melakukan penelitian yang berkaitan dengan netralitas yakni berjudul Kajian Netralitas Industri Media dalam Pemilu 2014. Kammaruddin menyimpulkan, telah terjadi adanya ketidaknetralan, dan ketidakindependensian serta objektifitas mass media pada kehidupan aktivitas politik kontemporer di Indonesia 2014. Industri media massa Indonesia merasa sulit untuk melepaskan diri dari kendala politik dan ekonomi. Secara politik dan ekonomi, media massa kontemporer telah melahirkan hegemoni, monopoli, kapitalisme maju, dan sistem kelompok. (Hasan, 2014).

Merujuk pada penelitian yang dilakukan oleh para peneliti sebelumnya menunjukkan, dua kelompok peneliti yaitu kelompok Emmy dan kelompk Ajeng dengan \& Heni meneliti prodak yang dihasilkan oleh mdia massa yaitu berita dengan cara menggunakan analisis isi, sedangkan penelitian yang dilakukukan oleh Musfialdy dan Kamarudin dengan cara mengumpulkan data yang di antaranya berasal dari pemeberitaan media massa lalu dianalisis oleh konsep dan teori yang relevan dengan tema tersebut. Penelitian yang dilakukan oleh peneliti kali ini sudah pasti sangat berbeda jauh dengan penelitian yang 
dilakukan oleh empat penelitian sebelumnya. Meskipun sama-sama menggunakan pendekatan kualitatif, tetapi peneliti lebih tertarik untuk meneliti sikap, pandangan dan pengalaman wartawan sebagai pelaku utama dalam proses pemberian informasi kepada masyarakat, sehingga data yang diperoleh lebih natural karena diberikan oleh informan inti yaitu wartawan sendiri.

Profesi wartawan adalah sebuah profesi yang memerlukan kerja keras dan berdedikasi tinggi, sebab dalam dunia wartawan erat berkaitan dengan pekerjaan yang cukup panjang, berkaitan pula dengan tempat liputan yang beragam dan suasana kantor yang dinamis. Selain itu, telepon yang setiap saat siap berdering, harus siap berangkat diwaktu yang masih gelap di saat orang lain tertidur. Pulang ke rumah di saat seluruh keluarga dan penghuni rumah sudah telah terlelap pulas, dan di saat yang lain sedang beristirahat menikmati liburan, bahkan ketika liburan panjang Hari Raya Keagaman pun wartawan tetap bertugas (Ishwara, 2011).

Wartawan adalah pelaksana pertama yang bertugas mengumpulkan semua informasi di lapangan untuk mendukung pembuatan berita yang akan disampaikan kepada masyarakat. Melalui bahasa yang dirangkai dalam sebuah kata, kalimat dan alinea lalu dipublikasikan kepada masyarakat, wartawan mampu merekonstrksi sebuah realitas social. Oleh karena itu tentu tidak terlalu bersalah jika seorang jurnalis sering dikatakan sebagai construction agent kejadian sosial yang terjadi di masyarakat.

Seorang wartawan juga-lah yang memberikan nuasa berbobot atau tidaknya sebuah lembaga media pers maupun media online, dengan demikian sangatlah beralasan jika wartawan menjadi salah satu ujung tombak yang sangat diadalkan oleh lembaga media massa. Wartawan bertugas dan bertanggung jawab tidak hanya membuat laporan berita yang sesuai dengan fakta dan data, wartawan juga tidak bisa dipungkiri ikut membuat definisi baru mengenai peristiwa di lapangan, dan tanpa disadari atau tidak wartawan bisa membawa pendengar, pemirsa dan pembaca kepada alam imajinasi dan alam pemikiran wartawan bersangkutan (Wibawa, 2012).

Lalu timbul pertanyaan, bagaimana sesungguhnya wartawan yang bertugas di Kota Bandung memandang mengenai netralitas media berdasarkan pengertian, pemahaman dan pemaknaan dan pengalaman mereka sendiri, dengan demikian penelitian ini bertujuan untuk mengakaji: 1). Bagaimana pengertian wartawan Kota Bandung mengenai netralitas media. 2) Faktor pemicu apa saja yang bisa membuat wartawan Kta Bandung mengimpeilmentasikan kenetralitasannya, dan 3) Bagaimana efek yang diterima oleh wartawan Kota Bandung setelah mengimplementasikan kenetralitasannya saat bertugas.

Penelitian ini diharapkan bermanfaat secara teknis bagi praktisi media, maupun para pengambil kebijakan yang berkaitan dengan media massa, serta 
diharapkan bermafaat bagi pengembangan ilmu khususnya di bidang Ilmu Jurnalistik terutama sebagai rujukan bagi pihak yang tertarik meneliti bidang eksistensi, peran dan fungsi wartawan maupun media massa. Oleh karena itu, dalam penelitian ini peneliti menggunakan pendekatan kualitatif. Dalam penelitian kualitatif, kedudukan teori tidak ditentukan diawal bahkan tidak diuji sama sekali sehingga kedudukan teori dalam penelitian kualitatif hanya sebagai pembimbing saja. Pernyataan tersebut didukung ahli pendekatan penelitian kualitatif S Nasution dan Faisal. Nasution meyakini teori pada penelitian kualitatif tidak bisa ditentukan sebelumnya. Penelitian tidak dimaksudkan untuk menguji atau membuktikan kebenaran teori tersebut. Teori tersebut bahkan dikembangkan berdasarkan data yang terkumpul (S. Nasution, 2016).

Senada dengan Nasution, Faisal menyatakan, peneliti kualitatif justru harus bisa membebaskan dari adanya tawanan sebuah teori (Faisal, 1990). Teori yang digunakan untuk membimbing pada penelitian yang peniliti lakukan adalah teori tindakan sosial Max weber, teori fenomenologi Alfred Schutz, teori interaksi simbolik George Herbert Mead. Teori-teori tersebut dugunakan hanya untuk menjelaskan realitas perilaku yang diperlihatkan wartawan secara subjektif saat mereka melakukan tugas dan tanggungjawabnya sebagai wartawan dalam memandang netralitas media secara umum.

Perilaku wartawan saat bertugas di lapangan yang dilandasi kenetralitasan bisa dilihat berdasarkan teori tindakan sosial yang dicetuskan Max Weber seorang Sosiolog dari Negara Jerman, sebab teori tidakan sosial lebih menitikberatkan pada makna subjektif yang diperlihatkan indivindu. Weber dalam Mulyana mendefinisikan perilaku tindakan sosial adalah sebagai semua perilaku manusia, ketika individu memberikan sebuah makna subjektif pada aspek perilaku tersebut (Mulyana, 2001). Pernyataan Weber tersebut mengisyaratkan, bahwa perilaku wartawan yang netral adalah sebuah perilaku yang memiliki makna subjektif.

Teori fenomenologis dari Alfred Schutz bisa dikatakan sebagai turunan atau varian dari teori tindakan sosial Weber, sebab teori ini masih berada di bawah payung teori tindakan sosial (Mulyana, 2001). Tidak berbeda jauh dengan asumsi teori tindakan sosial, pandangan fenomenologis pun tertarik pada pemaknaan subjektivitas, dengan demikian bagi Schutz tugas pokok fenomenologis adalah menganalisis merekonstruksi dunia kehidupan milik manusia "sebenarnya" yang tentu saja dalam lingkup yang dialmami mereka sendiri. Oleh karenannya pandangan fenomenologis ini cocok diterapkan untuk penilitian yang berkaitan dengan perilaku wartawan yang netra sebab dalam penelitian ini memberikan keluluasaan yang penuh kepada wartawan untuk mengungkapkan dunianya berdasarkan pengalaman yang dialami wartawan bersangkutan saat bertugas wartawan yang netral.

Teori interaksi simbolik dari Herbert Blumer juga akan membantu 
menjelaskan bagaimana wartawan memandang aktiitas sebagai wartawan berdasarkan pandangannya sendiri maupun orang lain. Teori interaksi simbolik juga bisa menjelaskan bagaimana wartawan bertindak atas dasar makna yang dimiliki oleh wartawan sebagai subjeknya, dan makna atau symbol-simbol tersebut merupakan proses dari hasil interaksi yang terjadi pada perilaku wartawan sebagai manusia lalu ditafsirkan oleh wartawan sendiri dengan melibatkan dirinya dan orang lain termasuk masyarakat.

Teori interaksi simbolik juga bisa menjelaskan makna dan simbol-simbol yang dipahami dan dipikirkan oleh wartawan dalam menuntukan tindakannya sebagai wartawan saat bertugas. Teori interaksi simbolik cocok untuk mendampingi penelitian karena asumsi dari teori ini adalah: 1). Manusia bertindak atas sesuatu menurut maknanya. 2). Makna itu tentu saja merupakan hasil interaksi sosial yang terjadi di masyarakat. 3). Makna itu dimodifikasi dan diproses melalui interpretasi, dan setiap proses interpretasi tersebut melibatkan tanda-tanda yang dihadapi setiap orang (Craib, 1994).

Metode penelitian deskriptif digunakan dalam penelitian ini, sebab pada penelitian ini memerlukan penggambaran perilaku wartawan, sedangkan pendekatan penelitiannya menggunkan pendekatan kualitatif. Prinsipnya, pendekatan kualitatif mengamati seseorang pada area lingkungan hidupnya, berinteraksi dan berusaha memahami bahasa dan menafsirkan mereka mengenai dunia sekitarnya (S. Nasution, 2016), dengan demikian pendekatan kualitatif ini prinsipnya mengamati wartawan dalam lingkungan hidupnya sendiri. Creswell mendefinikasikan kualitatif sebagai “...an inquiry process of understanding based on distinct methodological traditions of inquiry the explore a social of buman problem. The researcher builds a complex, bolistic picture, analyzes words, report, detailed, views of informant, and conducts the study in natural setting" (Creswell, 2007).

Teknik pengumpulan data dalam penelitian ini adalah observasi, wawancara dan kajian pustaka. Dalam observasi peneliti tidak hanya mengamati tetapi ikut serta bergaul dengan wartawan, karena pengamatan berperan serta bisa mengungkapkan mengenai bagaimana wartawan berperilaku. Dalam panggung belakang wartawan, wawancara bisa digunakan untuk menggali panggung depannya wartawan, karena itu teknik wawancara pun menjadi penting untuk memperoleh data dalam penelitian ini. Wawancara menurut Sugiono adalah teknik pengumpulan data yang bisa dilakukan dengan cara tidak terstruktur maupun terstruktur, juga bisa dengan cara langsung, atau menggunkan jaringan telepon maupun secara tatap muka (Sugiono, 2017).

Wawancara yang digunakan pada studi ini adalah teknik wawancara tidak terstruktur untuk mendapatkan sejumlah informasi yang dalam dari wartawan sebagai informan. Wawancara tidak struktur bersifat fleksibel sehingga bisa menggali secara leluasa gagasan, pandangan dan keinginan para informan. Penyusunan pertanyaan wawancara tidak struktur bisa disesuaikan dengan 
Darajat Wibawa

kebutuhan informan.

Dalam menentukan jumlah infoman peneliti mengacu pada pendapat Dukes, sedangkan penentuan kriteria infoman mengacu kepada pendapatnya Arikunto. Dukes dalam Creswell menyebutkan, dalam penelitian kualitatif boleh di lakukan dengan 3 sampai dengan 10 orang (Creswell, 2007). Meski standar yang diberikan kepada whistleblower Arikunto, target pemilihan sampel dalam penelitian ini akan mengikuti persyaratan, yaitu 1). Penentuan sampel penelitian harus didasarkan pada ciri tertentu yang menjadi ciri utama suatu populasi. 2). Tema sampel berisi fitur terbanyak yang ditemukan dalam populasi (tema kunci). 3). Karakteristik populasi ditentukan dengan cermat dalam studi pendahuluan. (Suharsimi, 2013).

\section{HASIL DAN PEMBAHASAN}

Berdasarkan wawancara dan pengamatan berperan serta kepada lima wartawan yang bekerja pada media massa yang berbeda-beda, diperoleh jawaban pengertian tentang netralitas media yang sangat beragam. Keberagaman tersebut paling tidak bisa dikelompokan dalam tiga katogori yaitu berkaitan dengan pengertian, netralitas sebuah kewajiban, implementasi netralitas adalah profesional dan penerapan solusi.

Prinsipnya para informan mengakui mengerti, dan memahami definisi netralitas sehingga mampu mendefinisikan mengenai netralitas secara beragam. Darsono, salah seorang informan dari Harian Pelita mengatakan, netralitas adalah keadaan tidak terikat dan bebas, tetapi jurnalis atau media massa mungkin saja tidak menganut netralitas karena ada kewajiban berpihak kepada pemilik modal.(Wawancara dengan Informan Darsono, 14 Maret 2020).

Pendapat senada disampaikan Zaenul informan dari Majalah Korpri. Menurut dia, netralitas artinya berimbang, akurat, tidak memihak, kecuali untuk kepentingan publik. Dalam kegiatan jurnalistik, terdapat prinsip independensi dan netralitas. Netralitas dan Independensi sangat lah berbeda, namun masih selaras dalam kesatuan yang satu sama lainnya tidak dapat terpisahkan. (Wawancara dengan informan Zaenun, 12 April 2020).

Menurut Deddy Ruswandi, infroman dari portal berita Wibawanews.net, netralitas dalam bahasa sederhana, berarti berada tengah-tengah. Netral berarti tidak peduli atau apatis. Keberimbangan media adalah upaya memberikan kesempatan ruang dan waktu kepada masing-masing pihak secara proporsional. (Wawacara dengan Dedddy Ruswandi, 5 Juni 2020)

Sementara menurut Agus Pras, informasi dari TVRI Jabar dan Banten, netralitas artinya berada di tengah-tengah, tanpa adanya keberpihakan (Wawancara dengan Agus Pras, 5 Juli 2020). Menurut Heryawan informan dari media online iNews.id, netralitas adalah suatu keadaan ketika wartawan memberitakan sebuah peristiwa sesuai suara hati nurani wartawan 
bersangkutan. (Wawancara dengan informan Heryawan, 11 April 2020).

Dari pendapat kelima informan tersebut, dapat disimpulkan bahwa netralitas adalah keadaan tidak terikat, bebas, berimbang, akurat, berada di tengah-tengah, tidak memihak, kecuali untuk kepentingan publik.

Pernyataan para informan juga didukung oleh Adian Husaini (2001) yang menyatakan jurnalistik tidak netral. Menurutnya, kegiatan menghimpun berita, mencari fakta, dan melaporkan peristiwa atau disebut jurnalistik tidak bisa dilepaskan dari rambu-rambu agamanya. Selain rambu agama, juga adanya aturan main lainya seperti undang-undang, dan kode etik jurnanalistik serta adanya intervensi dari pihak lain yang tidak bisa dihindari pengelola media.

Seperti yang disampaikan Arnus, selain aturan formal seperti Undangundang tentang pers no. 40 tahun 1999, wartawan juga harus taat dan tunduk kepada kode etik jurnalistik, yang bertujuan agar wartawan bisa bertanggung jawab dalam setiap menjalankan menjalankan profesinya. Mulai dari mencari, mengumpulkan, mengolah dan mempublikasikan infprmasi berupa berita. Secara sangat sederhana kode etik dapat diartikan sebagai kumpulan-kumpulan etika yang akan digunakan dalam sebuah profesi. Mengingat kode etiknya bagi jurnalis, maka kumpulan-kumpulam etika tersebut diperutukan bagi wartawan. Meski kode etik tidak memberikan sanksi secara fisik namun ada tetap sanki moral bagi setiap yang melanggarannya. (Arnus, 2014).

Upaya penguasa untuk mengendalikan media massa pun, tidak perlu ditampikan lagi. Bahkan upaya intervensi terhadap media massa yang dilakukan pemilik modal sudah pada kondisi terlihat jelas. Kelemahan lembaga media massa dalam soal finansial semakin membuka lebar intervensi melalui praktikpraktik menguasai pemberitaan dengan cara pemilik modal menitipkan berbagai berita yang dikehendaki oleh para pengusaha.

Menurut Susanto, upaya menciptakan relasi dengan para pejabat publik, para pemilik perusahaan media biasanya mereka menyampaikan pesan bersifat khusus lewat media miliknya dalam bentuk iklan ucapan selamat kepada pejabat public. Iklan tersebut tentu saja berisi memberi dukungan terhadap sebuah kebijakan yang dibuat oleh pejabat publik tersebut. Tindakan lain adalah dengan cara memanfaatkan sejumlah orang yang mempunyai berbagai keunggulan sosial maupun politik, diminta untuk berbicara di media dengan harapan sesuai dengan apa yang diharpkan para pejabat publik tersebut (Susanto, 2017).

Bill Kovach dan Tom Rosenstiel, mengatakan, netralitas bukanlah bagian dari prinsip jurnalisme. Menurutnya, jika jurnalis harus selalu menjaga sikap netral dalam menilai suatu fenomena, maka "kolumnis dan redaktur harus dikeluarkan dari profesinya (Kovach dan Resentiel, 2006). Bahkan, mereka harus bebas dari berbagai tekanan saat mengungkapkan apa yang mereka anggap benar. Independensi berita diperlukan, dengan demikian mereka bisa 


\section{Darajat Wibawa}

leluasa mengikuti keyakinannya untuk mengambil keputusan.

Media massa harusnya independen dan berfungsi dalam balutan kompetensi profesional. Media perlu berusaha dan melindungi atau menambah memperluas aspek otonominya secara relatif terhadap sumber utama kekuatan sistem politik dan sistem ekonomi yang membangun sikap yang objektif, netral, terbuka serta seimbang, sehingga membentuk "jarak" tertetu dari sentralistik kekuasaan tanpa menimbulkan konflik (McQuail, 2015).

Kovach pun mengingatkan agar pers menyampaikan berita yang berimbang, tidak boleh hanya menampilkan sisi baik atau buruk, melainkan harus benar dan utuh. Jika pers mengangkat berita yang serba buruk, maka akan terbangun masyarakat Indonesia yang skeptis, berpikir negatif, pesimistis, dan mudah menyalahkan pemerintah bahkan bangsa dan negara. Sebaliknya, jika pers terus menerus memberitakan hal-hal baik, maka tidak akan muncul kekurangan suatu negara sebagai bahan refleksi.

\section{Netralitas adalah Kewajiban}

Wartawan maupun media tidak boleh berpihak ke mana-mana, alias netral. Media memiliki kemampuan dalam memberikan pengaruh serta menciptakan publik opini. Pada sistem demokrasi, kemandirian dan kenetralan pemberitaan media massa harus selalu menjadi perhatian publik (Belekubun et al., 2015). Sedangkan menurut Musfialdy, jurnalis dan mass media memberikan sebuah gambaran yang nyata tentang dunia realitas dengan meminimalkan distorsi. Keyakinan tersebut bersumber dari asumsi tradisional yang menyatakan bahwa jurnalis adalah komunikator atau penyampai yang netral (Musfialdy, 2019).

Senada dengan Muslfialdy, dalam pers prinsip kemerdekaan dan netralitas harus dijunjung tinggi. Media independen dalam arti bebas menjalankan ideologi berita. Selain kepentingan umum, netralitas berarti keseimbangan, ketepatan, dan keadilan (Radjak:2017). Sedangkan menurut Hasan, netralitas, independensi atau objektifitas media massa menjadi syarat utama dalam menjaga keseimbangan antara kehidupan media massa sendiri dengan kehidupan politik dan publik (Hasan, 2014)

Berdasarkan pendapat Muslfialdy, Radjak dan Hasan mengisyaratkan bahwa wartawan diwajibkan besikap netral kepada semua pihak temasuk dalam membuat berita. Berita, sebagai isi media perlu diarahkan agar bermanfaat yang nyata bagi semua masyarakat dan khalayaknya, bukan hanya sekadar mampu membebaskan pengelola media massa dan pemiliknya dari sebuah kewajiban dan tuntutan serta keinginan masyarakat (Musfialdy, 2019). Menurut Radjak, netralitas merupakan kewajiban seluruh yang ikut dalam memproduksi berita media. Artinya, jika publik tidak menuntut sekalipun media bersikap netral, namun media tetap memiliki otonomi guna membuktikan mereka tidak mendukung kandidat tertentu (Radjak,2017). 
Media wajib menyajikan liputan yang berimbang (cover both side), melakukan check and rechech serta balancing reporting. Artinya masyarakat berhak memperoleh informasi yang netral, jujur dan benar (Hasan, 2014). Untuk menjaga integritas dan independensi, netralitas dan keberpihakan industri media mutlak diperlukan. Media harus menjauhi berbagai kepentingan kelompok dan individu. Media fokus pada data dan fakta serta kepentingan publik (Aguswandi et al., 2019). Perlu ada transparansi saat menyampaikan berita kepada publik. Jangan Beberapa ditutup-tutupi karena tuntutan publik akan berita objektif adalah tugas pers. Sepertinya tidak ada kabar untuk mendukung kelompok tertentu (Jiwarka dan Subagyo, 2014).

Sebuah Kewajiban dapat menjadi faktor memicu agar wartawan bisa netral terutama dalam membuat karya jurnalistik atau berita. Menurut informan Darsono, netralitas media dilaterbelakangi oleh kesadaran dan kewajiban wartawan untuk menegakkan netralitas dalam setiap aktivitas di lapangan termasuk menulis berita. Wartawan wajib bersikap netral berarti menjalankan amanat Kode Etika Jurnalistik (KEJ). KEJ inilah yang menjadi pedoman bagi wartawan sehingga mengetahui dengan pasti mana aktivitas yang boleh dilakukan wartawan dan mana aktivitas yang tidak boleh dilakukan oleh wartawan. (Wawancara dengan informan Darsono, 16 April 2020)

Sedangkan menurut informan Zaenul, netralitas wartawan terimplementasikan di lapangan karena dipucu oleh adanya kekhawatiran timbul reaksi yang mencolok dari masyarakat jika pemeberitaan yang ditulis wartawan tidak dilandasi netralitas. Berita yang tidak netral, akan menimbulkan reaksi dari pihak yang merasa dirugikan (Wawancara dengan informan Zaenul, 23 April 2020).

Deddy Ruswandi informan lainnya mengatakan, pelaksanaan netralitas harus dilaksanakan oleh wartawan jika tidak ingin mendapat protes keras dari masyarakat terutam dari pihak yang merasa dirugikan oleh pemberitaan. Karena itulah netralitas erat kaitannya dengan upaya tindakan konformasi yang perlu dilakukan oleh wartawan untuk menghasilkan karya jurnalistik yang berimbang. (Wawancara dengan informan Deddy Ruswandi, 25 April 2020)

Pemyataan senada disampaikan infrman Agus Pras dan Haeryawan. Agus Pras mengatakan, sikap netralitas dan keberimbangan dilaterbelakangi oleh kesadaran dan pemahaman dari para wartawan maupun pengelola media. Para wartwan menyadari bahwa untuk berkiprah di sebuah profesi, maka perlu mengikuti aturan main yang ada pada profesi tersebut, salah satunya aturan main mengenai netralitas (Wawancara dengan informan Agus Pras, 25 April 2020)

Sementara menurut informan Andri Herdiansyah, netralitas media dilaterbelakangi oleh kesadaran bahwa wartawan adalah sebuah profesi. Sebagaimana sebuah profesi, mensyaratkan keterkuasaan ilmu atau keahlian 
dan tanggung jawab. Ilmu atau keahlian bisa diperoleh dari institusi pendidikan atau pengalaman lapangan. Sedangkan tanggung jawab adalah bagaimana dalam menjalankan profesinya tersebut tetap sesuai aturan kode etik termasuk dalam penyajian berita yang harus netral sehingga bisa mengeliminasi kemungkinan buruk sebagai akibat dari pemberitaan yang dipublikasikan kepada masyarakat. (Wawancara dengan informan Heryawan, 22 April 2020)

Berdasarkan pendapat yang disampaikan oleh lima informan tersebut mengisyaratkan bahwa, netralitas dilaterbelakangi oleh adanya kesadaran awak media sendiri. Wartawan menyadari bahwa untuk menjalani profesi di dunia jurnalistik, harus mematuhi KEJ yang mensyaratkan penyajian berita yang netral. Pemberitaan yang tidak netral selain tidak sesuai dengan aturan KEJ juga bisa menimbulkan reaksi negatif dari para pihak tertentu, dan dapat merugikan masyarakat secara umum.

Dalam dunia jurnalistik, terdapat prinsip-prinsip netralitas dan independensi yang harus ditegakkan. Memang Kemerdekaan dan netralitas memang berbeda, tetapi tidak bisa dipisahkan. Media perlu menerapkan dua prinsip ini. Jurnalis Indonesia independen, dan beritanya akurat, berimbang, dan tidak berbahaya. Prinsipnya, kemerdekaan dan netralitas harus tercermin dalam kegiatan pemberitaan (Dewan Pers, 2006).

Selain itu, sesuai dengan kode etik penyiaran dan standarisasi program penyiaran yang diterbitkan Komisi Penyiaran Indonesia, juga disebutkan bahwa lembaga penyiaran memiliki kewajiban menjaga sikap independensi serta netralitas konten siaran di setiap program siaran. Menurut peraturan SPS, program siaran harus digunakan untuk kepentingan umum, bukan untuk kelompok tertentu tertentu, dan dilarang dimanfaatkan bagi kepentingan pribadi terurama pemilik dan kelompoknya. Selain itu, program berita harus akurat, netral, berimbang, serta adil.

Dalam kondisi apapun, seorang wartawan harus tetap perlu bersikap netralitas dan independen, sebab netralitas dan inependen adalah itulah jati diri sebuah profesi. Reporter atau wartawan tidak boleh dipaksa untuk bertindak, atau tidak. Namun demikian, sikap netralitas dan independensi wartawan bisa menghasilkan sesuatu yang kurang bagus, karena itu sikap netralitas dan independensi wartawan tetap perlu dikontrol. Alat kontrolnya adalah KEJ. KEJ adalah produk Dewan Pers yang tertuang dalam Surat Keputusan Dewan Pers Nomor 03/SK-DP/III/2006.

Keberadaan KEJ menjadi alat kontrol yang ampuh guna mencegah aktivitas wartawan yang liar, anarkis, dan egois, liar sebab KEJ memuat tentang aturan ketika wartawan menjalankan profesinya. Pasal $1 \mathrm{KEJ}$ mengisyaratkan bahwa, wartawan Indonesia perlu bersikap independen, perupaya untuk menghasilkan berita berimbang, akurat dan tidak beritikad buruk. Penafsiran Pasal 1 KEJ mengisyaratkan bahwa, sikap wartawan perlu didasari peristiwa 
ataupun fakta, juga berangkat dari suara hati nurani tanpa paksaan, campur tangandan intervensi dari pihak lain, bahkan pemilik perusahaan pers sekalipun (Dewan Pers, 2006).

Selanjutnya, pasal $3 \mathrm{KEJ}$ juga mengisyaratkan, wartawan Indonesia perlu menguji semua informasi, memberitakan secara berimbang, tidak mencampurkan fakta dan opini yang menghakimi, serta menerapkan asas praduga tak bersalah. Adapun yang dimaksud dengan berimbang menurut penafsiran pasal ini adalah memberikan ruang atau waktu pemberitaan kepada masing-masing pihak secara proporsional (Dewan Pers, 2006).

\section{Profesionalisme}

Wartawan maupun media perlu memiliki sikap netralitas dalam setiap aktivitasnya. Artinya, suka tidak suka wartawan perlu berusaha mencapai sikap yang netral jika ingin memperoleh predikat wartawan profesional yang benarbenar diinginkan masyarakat. Artinya, buah kinerja wartawan dan media yang netral adalah profesionalisme.

Alasan jurnalis harus profesional karena media bertujuan menghapus konten yang buruk dan yang tidak bertanggungjawab (Wardani \& Indrayani, 2018). Media selalu menyeleksi pertanyaan, informasi atau format konten berdasarkan kriteria pengelola dan pemilik. Pilihan sudut, arah, dan pembingkaian konten yang dianggap sebagai realitas cermin ditentukan oleh profesional media dan berdasarkan standar pemilik (Musfialdy, 2019)

Dalam proses gatekeeping banyak faktor yang bisa mempengaruhinya. Faktor tersebut di antaranya ideologi media, profesionalisme dan nilai-nilai wartawan (Radjak, 2017). Dalam menjalankan tugas kejurnalistikan, standar profesi jurnalis adalah mematuhi semua aturan dan kode etik jurnalistik. Salah satu kode etik penting bagi jurnalis yakni mewajibkan para jurnalis agar tidak memperoleh bayaran dari sumber berita (Anto, 2017).

Laporan pemberitaan berita di sebuah surat kabar adalah hasil dari alur sebuah pekerjaan profesional dan terorganisir yang menggunakan aturan dan keberadaan etika tertentu. Melihat peran aktivitas tersebut, surat kabar harus mampu berusaha memberikan sebuah informasi yang benar dan berimbang. Karena itu, media massa harus bersikap mandiri dan objektif agar masyarakat dapat memperoleh informasi secara proporsional (Poentarie, 2015).

Jurnalis profesional merupakan jurnalis yang melakukan aktivitas pekerjaannya sesuai pengetahuan atau profesinya yang berpegang pada kode etik jurnalistik dan tata cara pelaksanaan kegiatan pemberitaan. Selain itu, jurnalis yang profesional merupakan jurnalis yang memiliki tanggung jawab, setia, dan jujur, konsisten, netral, serta mampu menulis sesuai dengan kode etik jurnalis Indonesia (Wibawa, 2012). Reporter atau jurnalis merupakan profesi, oleh karenannya, wartawan perlu terikat pada prinsip profesionalisme sesuai 
Darajat Wibawa

bidangnya. Dengan kata lain, jurnalis adalah pekerja profesional yang harus memegang teguh etika jurnalistik (Wibowo, 2018).

Menurut para informan netralitas pada awalnnya memang hanya sebuah aturan yang harus dijalankan wartawan saat melaksanakan tugas. Seiring pekembangan waktu, aturan tersebut menjadi sebuah bagian yang tidak bisa terpisahkan dari aktivitas kehidupan di dunia wartawan. Oleh karenannya, pengimplementasian netralitas menurut para informan bisa berefek positif sehingga menjadi wartawan yang profesional, dan negatif sehingga menjadi wartawan yang tidak profesional. Dua kutub implementasi tersebut seolah saling tarik menarik yang tidak bisa dihindari lagi.

Kutub positip dalam pandangan para informan adalah aspek manfaat atau nilai guna ketika wartawan mengimplementasikan sikap netralitas saat bertugas. Menurut informan Darsono, manfaat, kegunaan, atau pengaruh positif netralitas bagi wartawan di antaranya bisa memperkecil perilaku yang tidak sesuai dengan aturan dengan demikian wartawan tetap bekerja sesuai dengan koridor aturan yang berlaku.

Abidin Zaenul informan lainnya berpendapat, manfaat dan kegunaan sikap netralitas dapat menunjang pekerjaan wartawan sebab secara tidak langsung sudah menjalankan KEJ sehingga kalaupun pun terjadi reaksi dari para pihak tertentu, wartawan memiliki landasan yang kuat yang bersumber pada KEJ. Manfaat wartawan bersikap netral bisa memberikan nilai positif dari masyarakat. Minimal masyarakat akan memberikan predikat bahwa wartawan bersangkutan adalah wartawan profesional karena selalu memegang teguh aturan nestralitas (Wawancara dengan informan Deddy Ruswandi, 25 April 2020)

Menurut informan Agus Pras, bersikap netral yang diperlihatkan wartawan bukan hanya memperoleh padangan sebagai wartawan profesional, juga dianggap mengargai sumber berita sehingga terjadi hubungan sosial yang baik antara wartawan dengan sumber berita. Artinya, sumber berita menaruh tingkat kepercayaan yang sangat tinggi. Sedangkan menurut informan Andri Herdiansyah, sikap netralitas yang ditujukkan wartawan akan memberikan pandangan positip pula kepada lembaga wartawan tempat bekerja dengan demikian kepercayaan masyarakat semakin meningkat.

Berdasarkan pendapat para informan tersebut menggambarkan bahwa, manfaat dan kegunaan bersikap netral, wartawan bisa menunjukan bahwa ia memberikan informasi yang seimbang, benar dan bekerja dengan benar karena dilandasi KEJ. Dengan demikian, akan memperkecil dampak negatif bagi wartawan bersangkutan, wartawan dan lembaga memperoleh citra positif dari masyarakat, bisa dikatakan sebagai wartawan yang profesional. Pernyataan informan didukung oleh Herfan (2015) yang menyataan, wartawan yang profesional adalalah wartawan yang memiliki kemampuan menyadari, mengerti 
dan memiliki keterampilan penuh untuk menunjang tugsanya. Wartawan dituntut untuk peka terhadap tanggung jawab sosial, paham mengenai visi dan misi media yang diikutinya, menguasai masalah teknik kewartawanan. Olehkarenanya, standar kompetensi wartawan menjadi lebih penting bagi wartawan di Indonesia.

Lebih jauh Herfan mengataan, KEJ juga harus tercermin dalam pemberitaan, sebab berita tersebut dibaca dan dipelajari para pembaca, sehingga para pembaca bisa menilai bahwa pemberitaan yang dibacanya mengadung informasi yang baik dan benar. Benar dan baik itu seperti yang terkandung dalam standar kompetensi bagi jurnalis. Standar kompetensi itu sendiri sudah bisa dipastikan melindungi para pembaca untuk mendapatkan informasi yang baik dan benar sesuai sesuai dengan Kode Etik Jurnalistik (Herfan, 2015)

Sedangkan menurut Parahita \& Raharjo, konsep dari keberimbangan mewajibkan media saat menyajikan laporan jurnalistik perlu adanya sikap keberimbang, tida berat sebelah, selalu cover multi side, tidak memihak, tidak berat sebelah. Oleh karenanya, hal ini sangat lah penting untuk dimanai secara mendalam oleh wartawan di mana pun berasal dari beragam media pun, termasuk wartawan media online terkait dengan kewajiban untuk memenuhi aturan dari kelayakan atau tidaknnya sebuah laporan pemberitaan ataupun sebuah informasi yang akan yang akan di sampaikan melalui beragam media massa termasuk media online karena secara sebab hal seperti ini bisa langsung memperngaruhi terhadap ke dalaman sebuah informasi serta kredibilitas media bersangkutan (Parahita \& Rahardjo, 2019)

Konsep keseimbangan menurut menurut Agustinii, kalangan wartawan memberikan perhatian yang khusus mengenai objetivitas. Bahkan menjadi perhatian pula bagi para pengambil kebijakan di Indonesia. Berkiatan dengan objektivitas ini, dewan pes sudah mengeluarkan sejenis pedoman yang disebut PPMS kependekan dari Pedoman Pemberitaan Media Siber yang mulai berlaku sejak tahun 2012 mengenai prosedur atau langkah-langkah mengenai prosedur atau pediman yang berkakitan dengan pemberitaan di media online atau media siber. Setiap berita wajib diverifikasi kecuali: 1). Berita mengandung kepentingan umum dan mendesak. 2). Menyebutkan identitas sumber berita, kredibel dan kompeten. 3). Sumber tidak diketahui keberadaannya dan tidak diwawancarai. 4). Beritanya masih memerlukan verifikasi (Agustinii, 2019).

Para informan juga mengatakan, jika wartawan bersikap netral, maka memberikan aspek positif, dengan demikian jika mengabaikan sikap netral maka memberikan aspek negatif terhadap wartawan dan lembaganya. Informan Darsono mengatakan, ketidaknetralan seorang wartawan membuat pekerjaan wartawan dipandang negatif. Wartawan yang tidak netral selain menyalahi KEJ, sangat riskan terjadinya komplain dari masyarakat. Abidin Zaenul informanya 
mengatakan, ketidaknetralan berarti kinerja wartawan tidak berdasarkan KEJ. Bila tidak menjalankan KEJ, wartawan dan medianya sangat rentan terhadap terjadinya gugatan oleh para pihak yang merasa dirugikan.

Sementara menurut informan Deddy Ruswandi, ketidaknetralan seorang wartawan bisa jadi masyarakat akan memosisikan wartawan/media bersangkutan sebagai pihak yang tidak profesional dalam menjalankan profesinya. Ketidaknetralan wartawan bisa membuat sumber berita tidak merasa dihargai, karena tidak diberikan kesempatan untuk menyampaikan informasi sesuai dengan pandangannya (Wawancara dengan Agus Pras, 5 Juli 2020).

Menurut Informan Andri Herdiansyah ketidaknetralan wartawan akan berpengaruh negatif bukan hanya pada seorang wartawan saja, melainkan kepada semua lembaga tempat bekerja sehingga citra wartawan dan lembaganya semakin menurun.

Berdasarkan pendapat para informan menujukkan bahwa, ketidaknetralan berpengaruh negatif pekerjaan wartawan dan medianya. Sikap media dan wartawan yang tidak netral selain menyalahi KEJ, juga sangat riskan terjadinya komplain dari masyarakat karena dirugikan oleh pemberitaan dengan demikian sangat rentan terjadinya gugatan, masyarakat juga akan memosisikan si wartawan/media bersangkutan sebagai pihak yang tidak professional. Prinsipnya, kegiatan jurnalistik adalah kegiatan untuk memindahkan sebuah realitas empirik ke dalam sebuah realitas karya mmedia. Namun realitas media bukanlah sebuah realitas yang bersifat empirik, dengan demkian perlu memenuhi sebuah standar yang bersifat objektivitas.

Objektivitas memiliki dua unsur, yaitu faktualitas dan impartialitas. Faktualitas adalah tentang kebenaran serta relevansi, sedangkan impartialitas berkiatan dengan netralitas dan keseimbangan. Akurasi dan kebenaran bisa dicapai bila wartawan dalam upaya menggali informasi selalu berusaha untuk senantiasa melakukan pengujian terhadap fakta dan data yang ditemukannya. Istilah yang sering digunakan dengan cara check dan recheck yang artinya menggali berbagai sumber untuk memperoleh informasi (Mursito, 2006).

Meskipun fakta dan data tersedia cukup banyak agar bisa dituliskan, tetapi jika fakta dan data itu tidak terkait langsung dengan sebuah peristiwa, maka berita yang dapat diungkap tidak akan lagi bersifat objektif, melainkan spekulatif dan menduga-duga. Terkait pemberitaan, media perlu berusaha memberikan ukuran porsi yang sama kepada semua sumber berita yang terkait dengan peristiwa tersebut. Ada aspek keadilan lainnya, yaitu netralitas. Terkait pemberitaan, media tidak boleh berpihak pada satu sisi atau sisi lain dari kejadian tersebut. Pers hanya bisa berdiri di satu sisi, dan itulah faktanya.

Penerapan Solusi, wartawan atau lembaga media massa yang tidaik netral akan memberikan dampak negatif terhadap perkembangan wartawan maupun 
media lembaga selanjutnya, untuk itu menurut para informan perlu segera ada solusi untuk mengurangi dampak negatif tersebut.

Untuk menanggulangi aspek negatif tersebut menurut para informan, bisa dilakukan dengan cara menjiwai dan menjalankan KEJ, dengan demikian akan terhindarkan dari komplain para pihak yang merasa dirugikan terhadap pemberitaan tersebut. Selain itu, memiliki kekuatan ketika suatu saat harus menghadapi gugat dari siapapun terkait pemberitaan yang tidak netral.

Para infroman juga mengakui, ketika wartawan menjalankan KEJ sebagai benteng agar tidak terjerumus kepada aspek keberpihakan wartawan akan mendapatkan nilai positif dari masyarakat, wartawan dan mediannya akan dianggap sebagai wartawan dan media yang profesional. Terpenting lagi ketika wartawan menjalankan pekerjaannya diladasi KEJ sehingga terhindar dari aspek keberpihkan maka narasumber merasa haknya diakomodir oleh wartawan dan mediannya.

Menurut para infroman, solusi lain yang bisa dilakukan oleh wartawan dan mediannya agar bisa menjalankan sikap netralitas adalah berusaha menjauhi sekaligus menghilangkan potensi-potensi yang bisa merusak penegakan sikap netralitas.

Berdasrakan pendapat para informan mengisyaratkan bahwa, untuk menanggulangi aspek negatif ketidaknetralan wartawan harus bekerja berdasarkan KEJ, dan berupaya menjauhi sekaligus menghilangkan potensipotensi yang bisa merusak penegakan sikap netralisme. Hampir semua lembaga profesional memiliki aturan main yang dituangkan melalui kode etik. Etika yang tertuang dalam sebuah kode etik memuat sebuah aturan dan norma, perlu diterima dan diberlakukan di sebuah kelompok profesi.. Etika berbeda dengan hukum, meskipun keduanya bersifat regulasi dan dapat digunakan sebagai kode etik. Di dunia wartawan, kode etik yang berlaku adalah kode etik wartawan Indonesia (KEWI)

Undang-undang nomor 40 tahun 1999 tentang Pers, khususnya bab 1 ketentuan umum pasal 1 poin 14 pada prinsipnya menyebutkan, kode etik jurnalistik adalah merupakan himpunan etika profesi kewartawanan. Berdasarkan pengertian tersebut, menggambarkan bahwa pengertian KEJ diartikan sebagai norma dan seperangkat bagi profesi kewartawanan. Artinya, aturan dan norma memiliki arti yang sangat penting bagi wartawan. Aturan dan norma itu memiliki tujuan agar para wartawan menempuh jalur terbaik saat bertugas menjadi wartawan di lapangan, sesuai dengan ketentuan aturan yang berlaku (Dewan Pers,2006)

Ketentuan KEJ adalah pedoman operasional bagi wartawan dalam melaksanakan tugasnya secara profesional dan tidak melanggar hukum. KEJ merupakan alat kontroling bagi para wartawan saat menjalankan tugas sebagai wartawan. Norma atau aturan yang terdapat dalam KEJ harus tetap 


\section{Darajat Wibawa}

dilaksanakan dan dipatuhi oleh wartawan ketika bertugas.

Pada dasarnya, etika jurnalisk dapat diartikan sebagai sebuah ketentuan mengenai aturan yang secara normatif wartawan secara profesional bekerja menyampaikan berita kepada khalaya. Profesionalisme adalah bagian dari kompetensi wartawan yang di dalamnya terdapat keterampilan yang di dukung oleh pengetahuan dan dilandasi kesadaran untuk mengimplementasukan fungsi dan tugas sebagai wartawan (Takalelumang et al., 2019).

Ciri kode etik adalah memberikan sanksi etik kepada anggota kelompok. Lingkup penerapan kode etik hanya untuk kelompok yang memiliki kode etik, yang dirumuskan oleh kelompok profesi terkait sesuai dengan aturan organisasi. Aturan KEJ disusun untuk membantu wartawan menentukan mana yang benar dan mana yang salah, yang berikiatan dengan baik atau buruk, dalam rangka turut serta bertanggung jawab dalam proses jurnalistik.

Menurut Hatta, pelaksanaan dan keberadaan kode etik jurnalistik adalah sebagai landasan moral ataupun norma yang berlaku pada profesi wartawan, lalu dihubungan dengan nilai-nilai atau kaidah para jurnalis ketika bertugas menjadi wartawan bisa memberikan arah dan pedoman tentang apa yang seharusatau tidak dilakukan, atau malah apa yang seharusnya ditinggalkan saja. Setiap kebebasan berekpresi melalui tulisan-tulisan yang diakmodir melalui lembaga pers, tentu saja mempunyai batasan dan ruang lingkup. Batasan dan ruang lingkup yang paling utama dan pertama bahkan tidak akan salah adalah apa yang keluar dari hati nuraninya. Dengan demikian, kebebasan pers bukan saja dibatasi oleh kode etik jurnalistiknya akan tetapi tetap ada hati nurani yang setiap saat berjalan. (Hatta, 2018)

Semua profesi di mana pun memiliki landasan moral yang harus dilalsanakan oleh para anggotanya. Begitu juga wartawan, dalam setiap aktivitasnya seperti menyampaikan berita dan infrmasi kepada masyarakat haruslah berlandasan moral. Landasan moral yang dipakai wartawan sering disebut dengan kode etik jurnalistik. Di Indonesia, setiap wartawan berkewajiban dan memiliki tanggung jawab untuk menerapkan kode etik jurnalistik dalam setiap aktivitasnya. (Christi \& Farid, 2020)

Berdasarkan pada aspek sejarah perkembamgan pers di Indonesia menunjukkan bahwa, sampai sejauh ini sudah terdapat sejumlah kode etik yang disusun dan dirumuskan serta diberlakukan oleh organisasi wartawan seperti Persatuan Wartawan Indonesia (PWI), maupun organisasi wartawan lainnya. Selain itu, ada juga kode etik yang memang dibuat dan disusun serta diberlakukan bersama pula, yaitu KEWI. Ekseistensi KEWI sudah disepakati oleh minimal 26 wartawan yang ada di Indenesia seperti organisasi wartawan cetak dan elektronik, termasuk PWI, Aliansi Jurnalis Indevenden, dan Ikatan Jurnalis Televisi Indnesia. 


\section{PENUTUP}

Para informan memberikan pengertian netralitas media yang sangat beragam dan kompleks namun pada prinsipnya mengarah pada kata tidak berpihak, dan berdiri sendiri. Para informan juga mengakui mengerti dan mengimplementasikan netralitas media adalah karena kesadaran untuk melaksanakan kewajiban sebagai wartawan. Sedangkan efek pengimplementasian netralitas media tertuju pada dua kutub, yaitu positf sehingga menjadi wartawan profesional dan negative sehingga menjadi wartawan yang tidak profesional. Guna meminimalisir kubu negatif informan mengakui perlunya sebuah solusi. Adapun solusi yang bisa dilaksanakan oleh para wartawan dan medianya adalah dengan cara bekerja yang dilandasi oleh KEJ. Solusi lainnya adalah berusaha menjauhi bahkan menghilangkan potensipotensi yang bisa mengganggu upaya penegakkan sikap netralitas.

\section{DAFTAR PUSTAKA}

Agustinii, A. (2019). Kompetansi kesadaran etika dan hukum pada wartawan televisi dalam menjaga objektivitas berita. Jurnal sosial humaniora, 10(2), 131. https://doi.org/10.30997/jsh.v10i2.2059

Aguswandi, A., Cangara, H., \& Sultan, M. I. (2019). Konstruksi Pemberitaan Partai Perindo di iNews TV. Jurnal Pewarta Indonesia, 1(2). https://doi.org/10.25008/jpi.v1i2.19

Anto, J., (2017) Kemerdekaan Pers di Sumut: Di Bawah Bayang Bayang Ancaman Diri. Jurnal Dewan Pers edisi 16 desember 2017.

Arnus, S. H. (2014). Industrialisasi Media Massa Dan Etika Jurnalistik. Jurnal Al-Munzir, 7(2), 14.

Belekubun, S., Unde, A. A., \& Cangara, H. (2015). Opini tokoh partai politik terhadap keberpihakan TV One dan Metro TV dalam pilplres 2014 di Sulawesi Selatan. Jurnal Komunikasi KAREBA, 4(2), 88-100.

Christi, H. E. J., \& Farid, F. (2020). Analisis Kode Etik Jurnalistik Pemberitaan Keberagaman di Media Online. Jurnal Koneksi, 4(1), 14. https://doi.org/10.24912/kn.v4i1.6495

Craib, I. (1994). Teori-teori Sosial. Modern. Jakarta. Raja Grafindo Persada.

Creswell, J. W. (2007). Research Design: Qualitative, Quantitative and Mixed Method Aproaches. SAGE Publications. https://doi.org/10.4135/9781849208956

Dewan Pers (2006). Kode Etik Jurnalistik, Jakarta: Dewan Pers

Faisal, S. (1990). Penelitian Kualitatif, Dasar dan Aplikasi. In Yayasan Asih Asah Asuh.

Hasan, K. (2014). Kajian Netralitas Industri Media dalam Pemilu 2014. Jurnal SUWA Universitas Malikussaleh, 53(9), 1689-1699.

Hatta, H. (2018). Tingkat Pengetahuan Dan Pemahaman Wartawan Terhadap Kode Etik Jurnalistk (Wartawan Kota1 Makassar). Jurnal Jurnalisa, 4(2). 
Darajat Wibawa

https://doi.org/10.24252/jurnalisa.v4i2.6897

Herfan, J. (2015). Peliputan Investigasi, Profesionalisme Wartawan Investigasi

Dan Interplay Antara Struktur Dan Agency. Jurnal Studi Komunikasi Dan

Media, 19(1), 23.

Husaeni, A. (2001). Jihad Osama Versus Amerika. Jakarta: Gema Insani Pers

Ishwara, L. (2011). Jurnalisme Dasar. Jakarta: Buku Kompasta.

Jiwarka, N. P. S., \& Subagyo. (2014). Keberpihakan Media Massa (Studi

Kualitatif Analisis Framing Konflik Nasdem antara Hary Tanoe dan.

Jurnal Komunikeasi Massa.

Kovach, B. T. R. (2006). Sembilan Elemen Jurnalisme. Jakarta: Pantau.

McQuail, D. (2015). Teori Komunikasi Massa McQuail, Edisi 6 Buku 1. Jakarta: Salemba Humanika

Mulyana, D. (2001). Metodologi Penelitian Kualitatif: Paradigma Baru Ilmu Komunikasi dan Ilmu Sosial Lainnya. Bandung: PT remaja Rosdakarya.

Mursito, B.M. (1999). Penulisan Jurnalistik: Konsep dan Teknik Penulisan Berita. Surakarta: Spikom.

Musfialdy, M. (2019). Independensi Media: Pro-Kontra Objektivitas dan Netralitas Pemberitaan Media. Jurnal Riset Komunikasi, 2(1), 21-28. https://doi.org/10.24329/jurkom.v2i1.50

Nasution, S. (2016). Metode Research (Penelitian Ilmiah. In Jakarta: Bumi Aksara.

Parahita, T. A., \& Rahardjo, T. (2019). Analisis Isi Tingkat Keberimbangan

Berita Rubrik News Dan Showbiz Yang Disajikan Dalam Portal Berita

Line Today. Jurnal Interaksi Online, 26(2), 21-42.

https:/ / ejournal3.undip.ac.id/index.php/interaksi-

online/article/view/23340/21325

Poentarie, E. (2015). Komparasi Kebenaran, Relevansi, Keseimbangan dan

Netralitas dalam Pemberitaan (Studi Konten Analisis Terkait

Pemberitaan Pemilu Presiden 2014 di Harian Kompas dan Koran Sindo)

The Comparasion of Truth, Relevance, Balance And Netrality In News

Reporting. Jurnal Studi Komunikasi Dan Media, 19(1), 1. https://doi.org/10.31445/jskm.2015.190101

Radjak, I. (2017). Analisis Yuridis Terhadap Netralitas Pers Pada Media Penyiaran Di Indonesia. Jurnal Lex Privatum Vol. V/No. 4/Jun

Sendjaja, S. D. (2006). Badan Hukum TVRI dan RRI sebagai Lembaga Penyiaran Publik. Jurnal Bisnis Dan Birokrasi, XIV(2), 498-514.

Sugiyono. (2017). Metode Penelitian Kuantitatif, Kualitatif, dan R\&D. Bandung: Alfabeta, CV

Suharsimi, A. (2013). Prosedur Penelitian: Suatu Pendekatan Praktik. Jakarta: Rineka Cipta.

Susanto, E. H. (2017). Media Massa, Pemerintah dan Pemilik Modal. Jurnal ASPIKOM, 1(6), 477. https://doi.org/10.24329/aspikom.v1i6.53 
Takalelumang, R., Senduk, J. J., \& ... (2019). Penerapan kode etik jurnalistik di media online komunikasulut. Jurnal Acta Diurna ... https:// ejournal.unsrat.ac.id/index.php/actadiurnakomunikasi/article/vi ew/25464

Undang-undang No. 40 tahun 1999 tentang Pers

Wardani, A. D., \& Indrayani, H. (2018). Netralitas Konten Berita Online (Analisis Framing: Berita Reuni Alumni 212 di detik.com). Interaksi: Jurnal Ilmu Komunikasi, 7(1), 1. https://doi.org/10.14710/interaksi.7.1.1-7

Wibawa, D. (2012). Meraih Profesionalisme Wartawan. MIMBAR, Jurnal Sosial dan Pembangunan, 28(1). https://doi.org/10.29313/mimbar.v28i1.345

Wibowo, A. P. (2018). Proporsionalitas Wartawan Televisi Lokal Di Batu Tv. Jurnal Nomosleca, 4(1). https:/ / doi.org/10.26905/ nomosleca.v4i1.2073 